\title{
Peculiarities of Power Transformation in the Modern Georgia
}

\author{
IRAKLI KAKHIDZE \\ DR \\ Grigol Robakidze University, School of Humanities and Social Sciences \\ e-mail: ngu.tiremadze(at)gmail.com
}

Keywords

power, information society, meritocracy, social media, electronic media

Abstract The most significant technological processes which began from the 2nd half of the 20th century and were followed by a significant increase of the role of information, changes in all areas of social life, led to transformation of power relations. The above-mentioned phenomenon was demonstrated by introduction of social media, enhancement of mechanisms of social involvement in the decision-making process and introduction of electronic democracy.

There is a difference of opinions in connection with the above-mentioned transformation results among the modern scientists which is expressed in the form of narratives of ,cyber optimist” and ,cyber pessimist” researchers. In this regard, peculiarities of power transformation in Georgia and its socio-political results are addressed in the article.

\section{Właściwości transformacji władzy we współczesnej Gruzji}

Słowa kluczowe władza, społeczeństwo informacyjne, merytokracja, media społecznościowe, media elektroniczne

Abstrakt

Najważniejsze procesy technologiczne, które rozpoczęły się w drugiej połowie XX wieku, wynikający z nich znaczący wzrost roli informacji oraz zmiany we wszystkich obszarach życia społecznego doprowadziły do transformacji stosunków władzy. Zjawisko to objawia się użyciem mediów społecznościowych, wzmocnieniem mechanizmów zaangażowania społecznego w proces decyzyjny i wprowadzeniem demokracji elektronicznej.

Wśród współczesnych naukowców nie ma zgody w kwestii oceny wskazanych zmian - badacze dzielą się na cyberoptymistów i cyberpesymistów. Z takiej perspektywy w artykule omówiono specyfikę transformacji władzy w Gruzji i jej efekty społeczno-polityczne. 


\section{Introduction}

The technological processes, development of information communication networks and a significant increase of the role of information which began from the 2nd half of the 20th century, served as the basis for significant changes in all areas of social life, including transformation of power relations. In this regard, practical examples of various countries are interesting. In professional literature, we often find reviews of cases of developed countries, which is natural, however, from scientific point of view, examples of other countries with various levels of development are also interesting. In this respect, the case of Georgia may be interesting, because it is a former post-Soviet country which has taken the path of European integration.

In this article, we will attempt to show peculiarities of power transformation in Georgia and its socio-political results.

\section{Methodology}

The empirical database for obtaining information about the issues to be studied is based on qualitative research methods, in particular, analysis of document and in-depth interviews. It should be mentioned from the beginning that a qualitative research has specific restrictions, which excludes review of data from quantitave and percentage prospective; the above restriction is solved in this survey using secondary data, which were obtained based on various administrative and scientific sources.

Within the framework of the survey, study of the target segment was conducted using indepth interviews. 18 interviews here conducted in total.

The survey respondents were divided into three main target groups:

- media experts,

- politologists and sociologists,

- "electronic democracy" experts and civil activists.

Such segmentation of respondents is predetermined by the specific nature of issues to be studied. In particular, the issue of power transformation has been studied from the perspective of meritocracy, social media and electronic democracy; accordingly, the opinion of experts of the above areas better demonstrates the practical aspects of the problem to be studied.

Reports and ratings of the following international, governmental and non-governmental organizations on the current condition of electronic involvement, media and Internet freedom in Georgia were obtained and analyzed during the research process: "Freedom House", ITU, CRRC, IDFI, E-participation in Georgia (eparticipationge.wordpress.com), Data Exhange Agency (dea.gov.ge), Citizen's Portal - My Electronic Government (my.gov.ge) etc.

\section{Peculiarities of power transformation}

First of all, it should be mentioned that the idea of transformation is related to the formation of "information society" (Masuda, 1980) and is demonstrated in several directions. It is primarily 
expressed in the function of granting power to information which implies expansion of spheres of influence of information and making it the most significant management resource. Information serves as the basis for improvement of the existing and new products and services, defines effectiveness of socio-cultural and management processes, therefore, information, as a resource, has gained the characteristics of capital (Castells, 2006). In this context, it is important that the education has also changed its character, nature and development strategy. It is rapidly updated in accordance with the changeable world and is transformed considering new needs.

One of the main peculiarities of informational society is the existence of a qualitatively different elite which consists of information workers and technocrats; therefore, we obtain "meritocratic" (Castells, 2006) governance where knowledge and possession of information represent the strategic resources for exercising power. The above layer of society is able to be adaptable to social changes which are common for informational society. Representatives of the new elite have started playing a leading role in formation and analysis of public opinion which preconditions their power advantage (Webster, 2006, p. 114-115).

Accordingly, not the one who possesses huge military force or wealth but the one who possesses and correctly disposes informational capital is dominating in the modern, i.e. informational society. Therefore, in this epoch, knowledge becomes the basis of power which qualitatively changes the nature of power.

The above characteristic represents one of the main indicators for describing the power transformation in informational society and qualitatively differs from all power resources previously existing in the history of the humankind (Webster, 2006, p. 37). Therefore, elite is institutionalized and is subject to permanent renewal. Accordingly, from this point of view, it is rather interesting to what extent the Georgian society meets the criteria of informational epoch.

The "meritocratic" governance model opposes the harmful practices existing in the post-Soviet countries, such as nepotism, oligarchy, clan governance etc. So, the human resources selected based on "meritocratic" principles are considered as one of the preconditions of political-economic development of the state.

Peculiarities of elite formation in Georgia are significantly related to the Soviet past where clan loyalty and informal relations represented the most significant factor of becoming part of the elite. According to the data of in-depth interviews, the dominating assessment made by respondents is that the above tendency continues and the present Georgian elite is clan-based; and informal relations, belonging to a specific clan, loyalty to the senior, and not the qualification, represent the most significant factors of becoming part of the elite.

The respondents look for the reasons of the current situation in the Soviet past and in the mentality of the Georgian society established under its influence. The Soviet past played a significant role in formation of cultural characteristics of society together with other factors and facilitated formation of mentality for which informal relations, clan system, nepotism, etc., are common.

The role of informal relations is so significant in achievement of success that in some cases even the baptismal service performed according to the Christian procedure does not have 
religious functions, but serves the goal of enhancement of the existing clan relations (Charkviani, 2014, p. 159).

Despite the above, a part of respondents accentuated that the existing system undergoes improvement and "meritocratic" principles are gradually introduced. The conditions of hiring employees and competition become more sophisticated as compared to the past periods, bribes for enrollment at the university or employing people are not taken etc. However, there are significant omissions and formal procedures in this respect too, which are defined by legislation, are often tailored to specific persons and as a result, pseudo-meritocratic promotion and incentive principles are in place.

During the survey, it was important to identify the issues which hinder introduction of meritocractic, career advancement system. In this regard, a part of respondents particularly accentuated the power of financial elites in the Georgian reality which is negatively evaluated and considered as the factor significantly hindering development of democracy because the financial elite is strongly connected with the power and its spheres of incluence expand more and more.

"Georgia undergoes so-called tycoonization which is a very unfavorable development for Georgia. Now, wealthy people actually go forward who try to create a new form of elite in Georgia". A.N., male media analyst.

Another significant hindering factor was the great influence of the so-called "intelligence" on the social life. The above group which consisted of cultural, scientific, art, etc., elite had the greatest influence on the Georgian political power since the Soviet period. According to some respondents, the two charismatic leaders in the modern history of Georgia - Zviad Gamsakhurdia and Mikheil Saakashvili attempted to reduce the limits of their power but this struggle resulted in the victory of the ,intelligentsia”; Eduard Shevardnadze and Bidzina Ivanishvili managed to settle the situation with them more or less effectively and use them for gaining and maintaining power.

Influence of church on power relations was named as one more significant hindering factor. Despite the fact that the church does not formally participate in politics, does not have official representatives in the legislative or executive power, the spheres of its infuence are still very wide, which is significantly preconditioned by a high rating in the society which is confirmed by results of one of the recent public opinion polls conducted in Georgia, in particular, according to the survey conducted by „International Transparency Georgia” in 2018, 76\% of population trusts the church (Transparency.ge, 2018).

One of the goals of the survey was to analyze whether the process of power transformation common for the information society plays a positive role in terms of public awareness and development of democratic processes in Georgia and what challenges exist in this regard.

This issue is also important from the perspective that the opinion about the positive role of Internet in the decision-making process by society dominates in the scientific literature on "information society", however there are sceptic opinions too. In this survey, similar to theoretical discoures, positions of respondents are presented in two directions - in the form of narratives of 
so-called "cyber optimists" and "cyber pessimists", however, the prevailing opinion is that the Internet creates a favorable platform for common citizens to play an active role in the decision-making process. The above phenomenon is primarily expressed in the opportunity of obtaining more alternative information, activation of the dialogue format and preparation of respective preconditions so that the user can become creator of information, public opinion leader and therefore, infuence the decision-making process. Activity in social media is already so effective that it makes the decision-makers respond to the painful topics disclosed there. This process is becoming more and more important and is positively associated with development of Internet and social networks.

As the information technologies have well demonstrated the huge potential for improvement of democratic life, new terms have been created: "electronic governance" (Rostiashvili, 2010), "electronic democracy” (Chadwick, 2018), "electronic participation” (Albrecht et al., 2008, p. 13) etc. These terms well reflect the process of power transformation in the democratic society.

One of the most visible indicators of power transformation is the development of social media whose role consistently increases, because it differs from the common informational influence due to the particular ability to influence the listeners. One of the most significant advantages of social media is that it allows for disseminating the news faster than traditional means of communication, radio and TV (Cohen, 2011).

Accordingly, development of social media made essential changes to the understanding of journalist and user, significantly changed the journalistic process common for the traditional media which is not associated only with the person having respective education, but so-called “civil journalizm" (Papathanassopoulos, 2011, p. 191) was developed, so, any citizen connected to the Internet is able to express his/her opinions and disseminate information. Social media facilitates to unite people who possess information and gives the users an opportunity to be available for the target audience everywhere and always. On the other hand, the information recipient is not a passive object anymore, but rather, feedback is established between the information issuer and recipient, the communication process becomes interactive and the user becomes the creator and disseminator of new information in this process (Murinska Gaile, 2013, p. 44-45).

Mainly an optimistic position prevails among respondents according to which development of social media in the Georgian reality enhances democratic tendencies and they remember examples of successful activities in the Internet which were created within the social media, developed there, then moved to the real space and brought a specific successful result. Interestingly, the activity indicated on the unofficial "online petition" page is named as one of the clear examples of the public "online-participation". In particular, it refers to the petition created on "manifest. ge" (Manifest.ge, 2018) in connection with the attempt of arrest of the director of the zoo in 2014. Despite the fact that it had no legal force, the government had to consider the existing reality as it saw the great protest from part of the public and did not exacerbate the situation.

Apart from achievement of the positive results of the above process, pessimistic opinions are also expressed by the Georgian society which result from observations on the society. Despite 
the fact that the survey participants recognize the great influence of the Internet, they at the same time accentuate the threats accompanying the "information society", in particular, enhancement of inequality (Meyer, 2002, p. 120) in the modern society which is based on the quality of access to information because one part of society has information, the skills of obtaining and processing information, while others lack this opportunity despite the fact the Internet creates a respective platform. In this regard, the situation is disproportionate, which is predetermined by that fact the people are not willing to study and analyze the situation thoroughly. This poses a threat of being dependent on one specific information channel; therefore, there is a higher chance of manipulating them.

The above tendency is also emphasized by the respondents and they support their position by specific empirical researches which is expressed by people mainly visiting the same information websites and establishing loyalty and high level of confidence in them, despite the objectively different reality regarding the relevance and level of reliability of the source (Papathanassopoulos, 2011, p. 38).

This observation is not new for the researchers interested in the above issue. Matthew Hindman provides data that most of people who use the new media to obtain information mainly visit several webpages. So, he concludes that despite abundance of information, it cannot be directly correlated to increase of democracy level. Rather, according to some researchers, the new media may even lead to weakening of democracy because "journalist citizens" disseminate a lot of unverified information. Social media researcher, Andrew Kean even asks a rhetoric question to describe this process - "Whom can we trust when everybody is an author?!" (Papathanassopoulos, 2011, p. 36).

Such sceptical mood coincides with the opinions of some experts participating in the survey. Their attitude to diverse and vast information is ambivalent to a certain extent which is expressed in a manner that the above fact cannot be perceived only positively. On the contrary, such diverse and unsorted information may even mislead the society.

A part of respondents have one more sceptical attitude that social media in Georgia makes the people attached to its network and live in a certain illusory world, regardless of their social status. These are politicians and their followers or just celebrities who share information for each other, show off before each other, but the reality presented on their Facebook pages online strongly differs from the objective reality. They create a certain "comfort zone" on Facebook where they are confined within their space and live in the "illusory world" because they have a feeling that their Facebook friends reflect the disposition of the society and at the elections they face a different reality. Therefore, in the opinion of respondents, social media often makes people live in the imaginary reality in Georgia.

Under the influence of the above phenomena, a new type of elites is formed, whose ideas and product of activities is a superficial, unqualified, and to a certain extent is an ,intellectual” fast food, but acceptable and tolerable for the specific nature of social media. Therefore, activity in this space facilitates their progress in social stratification. 
"New cultural elites, people who permanently publish posts and comment on something were formed in the social network; as a result, these people are invited to TV shows and afterwards, to politics. So, social media has become kind of department of Marxism-Leninism and History at Tbilisi State University in the past (during the Soviet Union) which was necessary means of becoming a part of the elite". A.E., male, politologist.

Sceptic experts also see a problem in terms of actual increase of electronic participation and user awareness mechanisms despite the fact that the above functions are considered to be the strength of Internet. In reality, there is an opposite phenomenon which is negatively reflected on social and political activism, in particular, social activity is often limited to "online" and not "offline", i.e. problems are not transferred to the real environment. Often a new topic is raised in social networks but negative emotions are discharged there and the protest is not taken out. Therefore, respondents find it difficult to talk about any positive, tangible results.

The above approach has its theoretical basis: despite the fact that there is a wide-scale political life in the Internet, it anyway distances people from the political life beyond the network. Though political actors may be actively engaged in online campaigns and lobbying, does not actually cause any change in politics. The reason for that is that the Internet does not facilitate making any significant changes to the political environment; it does not mobilize citizens for implementation of any specific actions. The only thing the Internet does, is holding active, heated political discussions (Dahlgren, 2005, p. 154).

Some respondents consider increase of populism and the scope of influence of populist politicians which pose threat to sustainable political systems as one of the factors hindering democratization; all the above will make democracy ineffective in the decision-making process.

Respondents also emphasize the opinion widely spread among the modern researchers that the Internet may be used to control the society. Though they cannot specify the clear examples of it in Georgia, but they speak of the theoretical possibility of its implementation.

It should be mentioned that some researchers point to not only the threat of surveillance from the part of the state but also fear that due to the decentralized function of the Internet, specific concerned groups can also do the same, which will increase the risks of surveillance on citizens even more (Mackay, O’Sullivan, 1999, p. 356). Michel Foucault talked about these threats before initiation of Internetization processes (Foucault, 1977).

Another sceptic opinion was that social media even transformed political processes, including democracy and created a need not for representative, but direct democracy where relations are mediated between the electorate and the leader. At the same time, social media is the ,protest media" by its meaning and no political discourses and consensus are created here, because there are very diverse opinions and all this may even lead to „counter democracy”.

\section{Conclusion}

The level of Internet freedom is high in Georgia, with increasing influence of social media and decision-makers have to consider the problems raised there to a higher extent. Therefore, 
according to the survey results, the opinion of Internet-optimists is dominant. However, negative aspects of this process were also outlined: “digital inequality”, using social media for „online entertainment" and not for cognitive purposes, stimulation of online activism and not the real one, using the Internet as a platform by marginal groups, which may even lead to "counter democracy", etc.

In terms of power relations, development of information society and introduction of meritocratic principles in formation of elites in Georgia cannot be done completely, the ruling elite is mainly formed based on clan principles. The main condition for becoming a part of the elite is informal relations, belonging to a particular clan and loyalty to the senior. The political and business elite are merged with each other creating a risk of tycoonization of political processes.

Despite these processes, power transformation facilitates improvement of the above system and introduction of meritocratic principles, rather than the opposite.

To conclude, it can be said that the power transformation process in Georgia is characterized by the same tendencies as all over the world, however, cultural and mental peculiarities create specific difficulties of this process. This may reveal the negative results more clearly and to a greater extent than it may occur in the developed European states where in addition to economic welfare, human rights are more protected and civil society is stronger.

\section{References}

Albrecht, S., Kohlrausch, N., Kubicek, H., Lippa, B., Märker, O., Trénel, M., Vorwerk, V., Westholm, H., Wiedwald, Ch. (2008). eParticipation - Electronic Participation of Citizens and the Business Community in eGovernment. Retrieved from: https://www.ifib.de/publikationsdateien/study_e-participation_engl.pdf (17.09.2018).

Bell, D. (1973). The Coming of Post-Industrial Society. New York: Basic Books.

Booth, P. (2010). Digital Fandom. New Media Studies. New York: Peter Lang.

Boyd, D. (2008). Why Youth (Heart) Social Network Sites. The Role of Networked Publics in Teenage Social Life. Cambridge: MIT Press.

Boyd, D.M., Ellison, N.B. (2007). Social Network Sites. Definition, History, and Scholarship. Retrieved from: https:// www.danah.org/papers/JCMCIntro.pdf (17.09.2018).

Caldwell, M., Henry, P. (2005). Celebrity Worship, Micro-Communities and Consumer Well-Being. Retrieved from: http://neumann.hec.ca/aimac2005/PDF_Text/CaldwellM_HenryP.pdf (17.09.2018).

Castells, M. (2006). The Informational Age: Economy, Society and Culture. Chichester-Malden: Wiley-Blackwell.

Chadwick, E. (2018). E-democracy. Retrieved from: https://www.britannica.com/topic/e-democracy (17.09.2018).

Charkviani, T. (2014). Neo-Patrimonial and Meritocratic Governance Strategies in a Transformable Public Service. Tbilisi: Ilia University.

Cohen, H. (2011). Social Media Definition. Retrieved from: https://heidicohen.com/social-media-definition/ (17.09.2018).

Dahlgren, P. (2005). The Internet, Public Spheres, and Political Communication. Dispersion and Deliberation. Political Communication, 2 (22), 147-162. DOI: 10.1080/10584600590933160.

Earl, J., Kimport, K. (2011). Digitally Enabled Social Change. Activism in the Internet Age. American Journal of Sociology, 6 (117), 1830-1832. DOI: 10.1086/664817.

Ellison, N.B., Lampe, C., Steinfield, Ch.W. (2009). Social Network Sites and Society. Current Trends and Future Possibilities. Interactions, 1 (16), 6-9. DOI: 10.1145/1456202.1456204.

Foucault, M. (1977). Discipline and Punish. London: Tavistock.

Hodkinson, P. (2011). Media, Culture and Society. An Introduction. Los Angeles: Sage. 
Karvalics, L.Z. (2009). Information Society Dimensions. Retrieved from: http://www.academia.edu/652113/Information_Society_Dimensions (17.09.2018).

Mackay, H., O’Sullivan, T. (1999). The media Reader. Continuity and Transformation. London: Sage.

Manifest.ge (2018). Retrieved from: https://manifest.ge/main/item/357 (17.09.2018).

Masuda, Y. (1980). The Information Society as Post-industrial Society. Washington: Transaction Publishers.

Meyer, T. (2002). Media Democracy. How the Media Colonize Politics. Cambridge: Polity Press.

Murinska Gaile, S. (2013). The Role and Functions of Social Media in Modern Society. Is Social Media Worthwile for Local Media? Journalism Research, 6, 43-62.

Papathanassopoulos, S. (ed.) (2011). Media Perspectives for the 21st Century. New York: Routledge.

Rosen, Ch. (2007). Virtual Friendship and New Narcissizm. The New Atlantis, 1 (17), 15-31.

Rostiashvili, K. (2010). E-Governance in Georgia: World Tendencies. Retrieved from: https://idfi.ge/ge/e-governance-in-georgia-world-tendencies (17.09.2018).

Transparency.ge (2018). Retrieved from: http://www.transparency.ge/ge/post/sazogadoebrivi-azris-kvleva-korupcia-nd oba-institutebis-mimart-da-sajaro-politikis-sakitxebi (17.09.2018).

Torres-Soriano, M. (2013). Internet as a Driver of Political Change. Cyber-Pesimists and Cyber-optimists. Journal of the Spanish Institute of Strategic Studies. Retrieved from: revista.ieee.es/index.php/ieee/article/download/40/68 (17.09.2018).

Tsuladze, L., Berdzenishvili, A., Esebua, F., Kakhidze, I., Macharadze, N., Kvintradze, A., Kldiashvili, D. (2013). Tendencies of social media development in Georgia - power of real virtuality?! Tbilisi: Publishing House „Meridian”.

Webster, F. (2006). Theories of the Information Society. London-New York: Taylor \& Francis e-Library. 